\title{
EFFECT OF PROTECTIVE CLOTHING UTILIZATION DURING SPRAYINGS OF PESTICIDES AND FERTILIZERS IN KHAMMAM DISTRICT TELANGANA STATE
}

\author{
E. JYOSHNA ${ }^{1}$, J. HEMANTHA KUMAR ${ }^{2}$, P. RAGHURAMI REDDY ${ }^{3} \&$ N. KISHORE KUMAR ${ }^{4}$ \\ ${ }^{1}$ Research Associate, Krishi Vigyan Kendra, Wyra, Khammam, Telangana, India \\ ${ }^{2}$ Programme coordinator, Krishi Vigyan Kendra, Wyra, Khammam, Telangana, India \\ ${ }^{3}$ Assistant Director of Research, Central Telangana Zone, Regional Agricultural Research Station, \\ Warangal, Telangana, India \\ ${ }^{4}$ Subject Matter Specialist, Krishi Vigyan Kendra, Wyra, Khammam, Telangana, India
}

\begin{abstract}
The present study is on effective usage f protective clothing during spraying of pesticides and fertilizers. Study has been conducted in the five locations of adopted villages of krishi vigyan Kendra, wyra Khammam district. The farmer rated the protective clothing as excellent in appearance, comfort ability and durability. Opinion of the farmers on protective clothing, adoption feasibility and the impact of protective clothing on occupational hazard was also discussed.

Keywords:
\end{abstract}

Received: Aug 11, 2017; Accepted: Aug 26, 2017; Published: Sep 02, 2017; Paper Id.: IJASROCT201714

\section{INTRODUCTION}

Pesticides are widely used in agricultural production, to prevent or control pests, diseases, weeds, and other plant pathogens in an effort to reduce or eliminate yield losses and maintain high product quality. Although, pesticides are developed through very strict regulation processes to function with reasonable certainty and minimal impact on human health and the environment, serious concerns have been raised about health risks, resulting from occupational exposure and from residues in food and drinking water (Christos A. Damalas and Ilias G. Eleftherohorinos. 2011).

In some situations, exposure to pesticides can occur from accidental spills of chemicals, leakages, or faulty spraying equipment. The exposure of workers increases in the case of not paying attention to the instructions, on how to use the pesticides and particularly when they ignore basic safety guidelines on the use of personal protective equipment and fundamental sanitation practices, such as washing hands after pesticide handling or before eating.

Several factors can affect exposure, during pesticide handling. The form of formulation of pesticide products may affect the extent of exposure. Liquids are prone to splashing and occasionally spillage, resulting in direct skin contact or indirect skin contact, through clothing contamination. Solids may generate dust, while being loaded into the application equipment, resulting in exposure to the face and the eyes and also respiratory hazards.

For example, workers who avoid mixing and spraying during windy conditions can reduce the exposure. Proper use and maintenance of protective clothing are considered as an important behavior, associated with 
reduced chemical exposures.

In this study, we used the protective clothing, particularly protective clothing is made out of the polyester and cotton blended garment. This garment can be new or a used old shirt. If it is old or used garment, we must make sure that it should not have any holes. Starch is applied to close the pores of the garment; here the starch is acted as a barrier between the skin and the chemical and for each usage starch application is must.

\section{OBJECTIVES}

- To observe the Suitability assessment

- To observe the Comfort ability assessment

- To observe the Durability/serviceability

- To observe the Adoption feasibility

- To observe the morbidity pattern/ occupational health hazards

\section{METHODOLOGY}

Study has been conducted in the five locations of adopted villages of Krishi Vigyan Kendra, Wyra Khammam district. Training programmes and method demonstrations have been conduted to the farmers, before starting the test of protective clothing and after that, protective clothing has been distributed to the farmers with clear instructions and the observations are recorded for one month. Farmer's feedback has been taken through the standardized schedules. This protective clothing technology has been taken up from the AICRP Home Science Textiles department, PG \& RC, PJTSAU, Rajendranagar. All the data was calculated through the standard rating scale. From the individual farmer opinion, the weighted mean score was calculated and this WMS score replicates the overall opinion of the five locations farmers.

\section{RESULTS AND DISCUSSIONS}

\section{Functional Features of Garments}

Table 1: Suitability Assessment

\begin{tabular}{|c|c|c|c|c|c|c|c|c|}
\hline $\begin{array}{c}\text { S. } \\
\text { No }\end{array}$ & $\begin{array}{l}\text { Suitability } \\
\text { Assessment }\end{array}$ & $\begin{array}{c}\text { Characteristics of } \\
\text { Functional Features }\end{array}$ & Excellent & Good & Fair & Poor & V. Poor & Wms \\
\hline 1 & Appearance & Superior & 26 & 4 & - & - & - & 4.8 \\
\hline 2 & $\begin{array}{l}\text { Length of the } \\
\text { garment }\end{array}$ & Sufficient & 20 & 7 & 3 & - & - & 4.5 \\
\hline 3 & $\begin{array}{l}\text { Size and shape of } \\
\text { the garment }\end{array}$ & Appropriate & 25 & 5 & - & - & - & 4.83 \\
\hline 4 & $\begin{array}{l}\text { Size and shape of } \\
\text { collar }\end{array}$ & Appropriate & 24 & 6 & - & - & - & 4.8 \\
\hline 5 & $\begin{array}{l}\text { Size of sleeves } \\
\text { and cuffs }\end{array}$ & Appropriate & 19 & 9 & 2 & - & - & 4.5 \\
\hline 6 & $\begin{array}{l}\text { Size and } \\
\text { placement of } \\
\text { pockets }\end{array}$ & Convenient & 17 & 8 & 5 & - & - & 4.4 \\
\hline 7 & $\begin{array}{l}\text { Placket opening } \\
\& \text { fasteners of the } \\
\text { garment }\end{array}$ & Suitable & 20 & 10 & - & - & - & 4.6 \\
\hline
\end{tabular}

Table no 1 consists of all the suitability components like appearance and the characteristics of functional feature is superior. Out of the thirty farmers, 26farmers had given the excellent and four farmers had given good, feedback. The 
weighted mean score was 4.8 , which replicate the overall appearance of the garment as excellent.

Sufficient Length of the garment, as the characteristic functional feature, 20 farmers responded as excellent, 7 perceived it as good and 3 rated it as fair. The overall Wms score was 4.5, which indicates that the length of the garment is sufficient for the farmers, for protection towards the fertilizer application.

Size and shape of the garment Characteristics of functional feature is appropriate and out of 30 farmers 25 gave excellent feedback, and 5 gave good feedback. The overall Wms score was 4.8, which indicates the size and shape of the garment is good, so the size and shape of the garment is not affecting the farmer's activity, during the fertilizer application.

Size and shape of collar characteristics of functional feature is appropriate and out of 30 farmers 24 gave excellent feedback and 6 gave good feedback. The overall Wms score was 4.8, which indicates the size and shape of collar is appropriate to the particular protective clothing.

Size of sleeves and cuffs characteristics of functional feature is appropriate and out of 30 farmers 19 farmers had given the excellent feedback, 9 farmers gave good feedbak and two farmers gave fair response. The overall Wms score was 4.5, which indicates that the size of sleeves and cuffs are appropriate to the protective clothing.

Size and placement of pockets characteristics of functional feature is convenient and out of 30 farmers, 17 farmers had given the excellent feedback, eight farmers gave good and five farmer gave fair response. The overall Wms score was 4.4, which indicates that, the size and placement of pockets are convenient to the protective clothing.

Placket opening \& fasteners of the garment characteristics of functional feature is suitable and out of thirty farmers, 20 gave excellent feedback and 10 gave good feedback. The overall Wms score was 4.6, which indicates that the placket opening \& fasteners of the garment is suitable to the protective clothing.

Table 2: Comfort Ability Assessment

\begin{tabular}{|c|c|c|c|c|c|c|c|c|}
\hline S. No & $\begin{array}{c}\text { Comfort Ability } \\
\text { Assessment }\end{array}$ & $\begin{array}{l}\text { Characteristics of } \\
\text { Functional Features }\end{array}$ & Excellent & Good & Fair & Poor & V. Poor & Wms \\
\hline 1 & Easy to wear & & 26 & 4 & - & - & - & 4.8 \\
\hline 2 & Easy to remove & & 27 & 3 & - & - & - & 4.9 \\
\hline \multirow[t]{4}{*}{3} & $\begin{array}{l}\text { How long can be } \\
\text { worn }\end{array}$ & 1. $0-1 \mathrm{hr}$ & 27 & 3 & - & - & - & 4.9 \\
\hline & & 2. $1-2 \mathrm{hr}$ & 24 & 6 & - & - & - & 4.8 \\
\hline & & $3.2-3 \mathrm{hr}$ & 17 & 9 & 4 & - & - & 4.4 \\
\hline & & 4. More than $3 \mathrm{hrs}$ & 12 & 8 & 7 & 3 & - & 4 \\
\hline \multirow[t]{2}{*}{4} & Fabric & $\begin{array}{l}\text { Protects body from } \\
\text { external matters }\end{array}$ & 22 & 8 & - & - & - & 4.7 \\
\hline & & $\begin{array}{l}\text { Absorbency of } \\
\text { perspiration/pesticide }\end{array}$ & 19 & 7 & 4 & - & - & 4.5 \\
\hline
\end{tabular}

Table no 2, consists of information regarding comfort ability assessment components, like Easy to wear and 26 farmers gave excellent feedback, while four of them assessed comfort ability as good. The overall weight mean score was 4.8, which indicates that, the protection clothing is easy to wear and it is not felt very difficult, by the farmers.

Easy to remove: out of 30 farmers, 27 gave excellent feedback and three gave good feedback. The overall Wms score was 4.9, which indicates that, the protective clothing is easy to remove, for the farmers and are not facing any problem, while removing after their agricultural operations. 
The comfort ability assessment also included the duration the clothes can be worn comfortably. The study revealed that, 27 farmers perceived the clothing comfort ability as excellent during first hour. The comfort ability of clothing was perceived as excellent by 24 farmers during 1-2hrs of duration, while only 17 farmers rated comfort ability as excellent when it was worn for 2-3hrs. When the protective clothing was worn for more than 3 hrs, comfort ability was found to be excellent by only 12 farmers. The farmers are not feeling comfortable to wear the protective clothing, why because the starch gets absorbed by the chemical, as well as at the time of spraying the farmers sweat and eventually, the dress sticks to the body creating discomfort.

Fabric characteristics of functional feature are to protect body from external matters and out of 30 farmers, 22 gave excellent feedback and 8 gave good feedback. The overall Wms score was 4.7, which indicates that, the fabric is protecting the body from the external matter. Absorbency of perspiration/ pesticide and out of thirty farmers, 19 gave excellent feedback, seven gave good and four gave fair response and the Wms score was 4.2, which indicate that this protective clothing is absorbing the perspiration/ pesticide.

Table 3: Durability/Serviceability

\begin{tabular}{|l|l|l|c|c|c|c|c|c|}
\hline S. No & $\begin{array}{c}\text { Comfort Ability } \\
\text { Assessment }\end{array}$ & $\begin{array}{c}\text { Characteristics of } \\
\text { Functional Features }\end{array}$ & Excellent & Good & Fair & Poor & V. Poor & Wms \\
\hline 1 & Garment old/new & $1.0-5$ days & 27 & 3 & - & - & - & 4.9 \\
\hline & & $2.5-10$ days & 25 & 5 & - & - & - & 4.8 \\
\hline & & $3.10-20$ days & 23 & 4 & 3 & - & - & 4.6 \\
\hline & & 4. Entire crop period & 12 & 10 & 5 & 3 & - & 4 \\
\hline
\end{tabular}

Table no 3 is showing the durability/serviceability of the protective clothing for 0-5 days and 27 farmers gave excellent and three gave the good response and the Wms score was 4.9, which means the 0-5 days durability is good. Serviceability of the clothing in 5-10days: twenty five farmers gave excellent and five gave good response and the Wms score was 4.8, which replicate that 5-10 days durability is good. 10-20 days: out of 30 farmers 23 gave excellent, 4 gave good and 3 gave fair response the Wms score was 4.6, which indicate that 10-20 days, they can use for spraying. Entire crop period: out of 30 farmers 12 gave excellent, 10 gave good, 5 gave fair and 3 farmers gave poor. The Wms score was 4.4, which indicate that fair response to the protective clothing, whether it is the old garment or the new garment, it can be easily used for the entire crop period.

Table 4: Adoption Feasibility

\begin{tabular}{|l|c|l|c|c|c|c|c|c|}
\hline S. No & $\begin{array}{c}\text { Adoption } \\
\text { Feasibility }\end{array}$ & $\begin{array}{c}\text { Characteristics of } \\
\text { Functional Features }\end{array}$ & Excellent & Good & Fair & Poor & V. Poor & Wms \\
\hline 1. & $\begin{array}{l}\text { Cost of the New } \\
\text { garment (Rs 650/-) }\end{array}$ & Reasonable & - & 15 & 10 & 5 & & 3.3 \\
\hline
\end{tabular}

Table no 4 is showing the adoption feasibility cost of the New garment (Rs 650/-), the characteristics of functional feature is reasonable: out of 30 farmers, 15 gave good, 10 gave fair and 5 gave poor response and the Wms score was 3.3, which indicates that, the farmers are feeling that the cost is high. Instead of going for new, they prefer using the good condition old garment as protective clothing

Table 5: Opinion of the Respondent Regarding Protective Clothing

\begin{tabular}{|c|c|c|c|c|c|}
\hline S. No & Statements & $\begin{array}{c}\text { Strongly } \\
\text { Agree }\end{array}$ & Agree & Disagree & Wms \\
\hline 1. & Old shirt protect neck from dust and other organic & 25 & 5 & - & 2.8 \\
\hline
\end{tabular}




\begin{tabular}{|c|c|c|c|c|c|}
\hline & $\begin{array}{l}\text { matter, so there is no need of specially designed } \\
\text { protective clothing }\end{array}$ & & & & \\
\hline 2. & I feel good with old shirt as Iam habitual to wear it. & 30 & - & - & 3 \\
\hline 3. & $\begin{array}{l}\text { Functional features/fasteners used in protective } \\
\text { clothing do not cause pinching }\end{array}$ & 30 & - & - & 3 \\
\hline 4. & $\begin{array}{l}\text { protective clothing though look different still one } \\
\text { should wear these as health protection is important } \\
\text { than look }\end{array}$ & 24 & 6 & - & 2.8 \\
\hline
\end{tabular}

Table no 5 indicates that, opinion of the respondents regarding the protective clothing old shirt is fulfilling and their needs were that, it is protecting from the organic matter and dust so there is no need of specially designed protective clothing. Farmers are feeling good with the old shirt because they are habituated. Functional features/fasteners used in protective clothing, do not cause pinching to the respondents and with those features, they are not having any problem. Farmers strongly agree with it, even though the protective clothing look different they want to wear because, health and protection was considered important, than look

Table 6: Adoption Feasibility of the Respondents Regarding Protective Clothing

\begin{tabular}{|c|c|c|c|c|c|}
\hline S. No & Statements & $\begin{array}{l}\text { Strongly } \\
\text { Agree }\end{array}$ & Agree & Disagree & Wms \\
\hline 1. & $\begin{array}{l}\text { One must wear protective clothing to avoid health problems } \\
\text { during agricultural activities }\end{array}$ & 24 & 6 & - & 2.8 \\
\hline 2. & $\begin{array}{l}\text { It is better to spend money on protective clothing rather than } \\
\text { to spend money on health diseases/problems }\end{array}$ & 23 & 7 & - & 2.7 \\
\hline 3. & Protective clothing are the needs of every farm workers & 15 & 15 & - & 2.5 \\
\hline 4. & $\begin{array}{l}\text { To avoid health problems faced by farm workers with the } \\
\text { use of normal clothing, everyone will use Protective clothing } \\
\text { during working hours }\end{array}$ & 20 & 10 & - & 2.6 \\
\hline
\end{tabular}

Table no 6 shows the adoption feasibility of the respondents, regarding protective clothing and farmers strongly agree to the fact that, one must wear protective clothing to avoid health problems during agricultural activities. Farmers feel that, it is better to spend money on protective clothing rather than to spend money on health diseases/problems. In the agricultural operations, protective clothing is needed to avoid the health problems.

Table 7: Morbidity Pattern/ Occupational Health Hazards

\begin{tabular}{|l|c|c|c|c|c|c|c|c|}
\hline \multirow{2}{*}{ Parameter } & \multicolumn{2}{|c|}{ Daily } & \multicolumn{2}{c|}{ Weekly } & \multicolumn{2}{c|}{ Quarterly } & \multicolumn{2}{c|}{ Monthly } \\
\cline { 2 - 9 } & NC & PC & NC & PC & NC & PC & NC & PC \\
\hline Itching & 30 & 20 & 25 & 13 & 26 & 5 & 27 & 0 \\
\hline Irritation & 30 & 20 & 25 & 12 & 27 & 5 & 26 & 0 \\
\hline Skin allergies & 30 & 22 & 30 & 14 & 24 & 8 & 25 & 0 \\
\hline Burning & 25 & 22 & 25 & 12 & 25 & 5 & 25 & 0 \\
\hline Vomiting & 20 & 23 & 20 & 10 & 22 & 5 & 22 & 0 \\
\hline Headache & 25 & 20 & 22 & 8 & 25 & 5 & 25 & 0 \\
\hline Faintness & 25 & 18 & 25 & 7 & 26 & 5 & 25 & 0 \\
\hline
\end{tabular}

Table no 7 is clearly showing the morbidity pattern/ occupational health hazards of the respondents, majority of the farmers re suffer from various health hazards, because of not taking any safety measures during the spraying of chemicals like itching, irritation, skin allergies, burning, vomiting, headache and faintness. With the protective clothing utilization, the health hazards were decreased, when comparing with the normal clothing. Over a period of time, the symptoms were decreased from day one to day 30. 


\section{CONCLUSIONS}

Exposure to the chemical pesticides while spraying in the field has become a major health problem, among the farmers. By taking safety measures, these health problems can be reduced. So, Krishi Vigyan Kendra popularized the protective clothing technology to the farmers, to reduce the health hazards. Here, the polyester and cotton blended garment with the starch application for each spraying was used as a protective clothing. The suitability, comfort ability, durability, adoption feasibility and opinion of the farmers were good. By this protective clothing utilization, the morbidity/ health hazards were decreased, among the farmers as well as productive agricultural work output increased, among the farmers using protective clothing.

\section{REFERENCES}

1. Christos A. Damalas and Ilias G. Eleftherohorinos. 2011. Pesticide Exposure, Safety Issues, and Risk Assessment Indicators. Int. J. Environ. Res. Public Health 2011, 8, 1402-1419; doi: 10.3390. 